\title{
En kvinne med leggødem og arrforandringer
}

\author{
En kvinne utviklet bilateralt lymfødem i legg og fot med papillomatøse \\ hudlesjoner. Dessuten var de ytterste delene av fingrene fortykket
} og hun hadde exophthalmus. Hos henne ga tidligere sykehistorie med Graves' sykdom tips om diagnosen.

Se kommentar side 752 og kunnskapsprøve på www.tidsskriftet.no/quiz

En kvinne i 60-årene ble henvist på grunn av uttalt lymfødem med papillomatøse forandringer på fotrygg og over tær.

Leggødem er en vanlig problemstilling i den kliniske hverdag. Lymfødem er resultat av medfødt eller akvirert svikt i lymfekarenes evne til drenasje av lymfe. Akvirert svikt kan oppstå etter infeksjoner, kirurgi, strålebehandling eller andre tilstander som kan komprimere lymfekarene. Lymfødem gir i starten et pittingødem, som etter hvert utvikler seg til et ikke-pittingødem hvor huden har redusert turgor med hyperpigmentering, hyperkeratose og papillomatøse eller verrukøse forandringer. Lymfescintigrafi kan skille lymfødem fra venøs svikt i tvilstilfeller. Histologisk undersøkelse vil avdekke avvik i blodkar, lymfeårenes struktur, malignitet eller proteinavleiringer. Ved bilateralt lymfødem bør okklusive prosesser i bekkenet utelukkes. Lymfødem kan også oppstå sekundært til tidligere kirurgi i bekkenet.

Hun ble behandlet med radioaktivt jod for Graves' sykdom da hun var nesten 40 år gammel. Hun hadde da utviklet exophthalmus, som forverret seg under og etter behandlingen. Hun utviklet også glaukom. Det ble ikke gitt steroider under behandlingen. Hun ble substitusjonsbehandlet med tyroksin og etter ti år utviklet hun hevelse og tyngdefølelse $i$ begge beina. Hun hadde røykt 10-20 sigaretter per dag fra 15 års alder. Ved klinisk undersøkelse fant man symmetrisk ikke-pittingødem fra tær, føtter og oppover leggene (fig 1). Huden var blekrosa med papillomatøs overflate som over tær og fotrygg dannet tumorliknende lesjoner (fig 2).

Graves' sykdom er en systemisk sykdom som etter hvert kan gi ekstratyreoidale organmanifestasjoner (1). Thyreoideadermopati kalles ofte pretibialt myksødem da predileksjonsstedet er fortil på legger og da hyppig symmetrisk. Tidvis involveres føtter og tær, men andre lokalisasjoner ses også (1). Myksødem (myxodes = slimaktig) skyl- des avleiring av mucin (slim). Det kan manifestere seg som spredte gulbrune eller hudfargede noduler eller plakk som er kosmetisk skjemmende, men oftest ikke til plage for pasienten. Det er imidlertid ikke helt uvanlig med lesjonell hyperhidrose (1). I enkelte tilfeller utvikler det seg et uttalt regionalt ikke-pitting lymfødem med verrukøse tumormasser, også kalt elephantiasis (1). Siden myksødem kan utvikles i mange ulike varianter lenge etter thyreoideasykdommen, kan diagnosen være vanskelig å stille. Både nekrobiosis lipoidica og kreft kan være aktuelle differensialdiagnoser.

Biopsi fra fotrygg viste hyperkeratose i epidermis, kollagenbånd med rikelig mucin forenlig med pretibialt myksødem.

Diagnosen myksødem stilles ved funn av store mengder mucin i den retikulære del av dermis og med noen få lymfocytter perivaskulært. Det er moderat økning av mastceller, redusert antall kollagene fibre og markert ødem sammenliknet med normal hud (1). Fibroblastene produserer fibre og mesteparten av grunnsubstansen i ekstracellulær matriks hvor hyaluronsyren er det dominerende glykosaminoglykanet (mucin). Fibroblastenes produksjon av hyaluronsyre stimuleres av insulinliknende vekstfaktor 1 (IGF-1). Et hydrert molekyl hyaluronsyre binder 10000 ganger mer vann enn samme mengde albumin (2). Ved Graves' sykdom er fibroblastenes produksjon av hyaluronsyre kraftig økt $(1,2)$. Mucinavleiringen gir væskeretensjon og kompresjon av små perifere lymfekar med sekundær utvikling av lymfødem. Avleiring av mucin er patognomonisk for alle ekstratyreoideale manifestajoner ved Graves' sykdom. Mucinavleiringen er muligens også bakgrunnen for selve strumautviklingen (2).

Hun var i under middels hold, og hadde bilateral exopthalmus og fortykkelse av ytterdelene på alle fingrene, såkalte trommestikkfingre (clubbing). CT abdomen og bekken viste normale forhold, uten okklusive prosesser. Blodprøver viste s-TSH-R-ab (TSH-reseptorantistoff) > 40, TSH 1,9 $\mathrm{mU} / \mathrm{l}$, fritt T4 20,3 pmol/l, T3 2,8 pmol/l.

Det er holdepunkter for at både hypertyreosen og de ekstratyreoidale manifestasjonene ved Graves' sykdom skyldes cellulær påvirkning av TSH-reseptorantistoff (1).

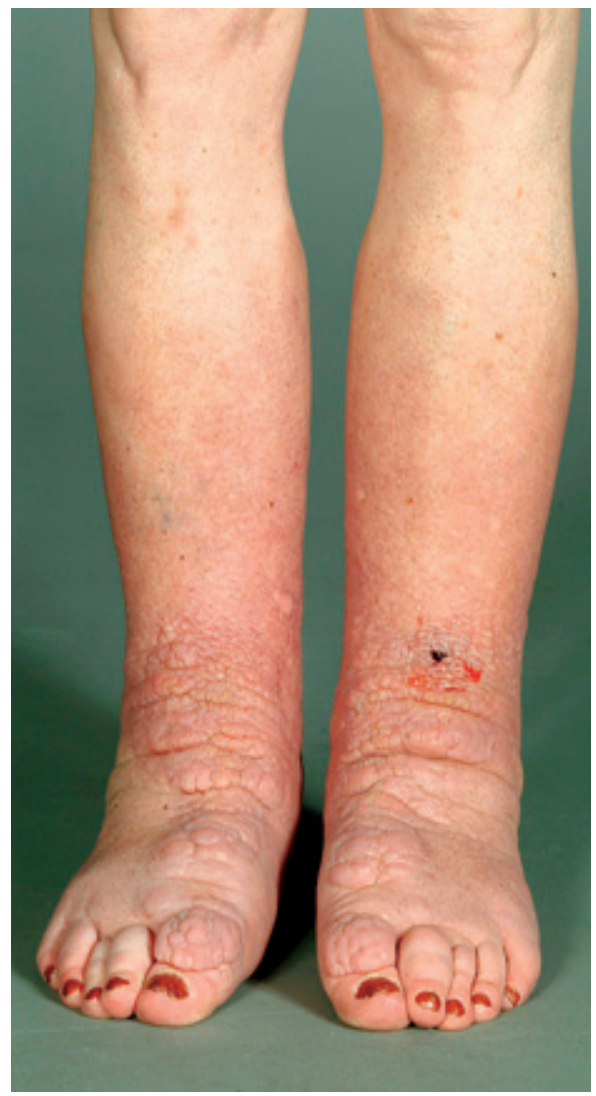

Figur 1 Thyreoideadermopati lpretibialt myksødeml hos kvinne i 60-årene. Symmetrisk lymf$ø$ dem fra tær og føtter oppover legger

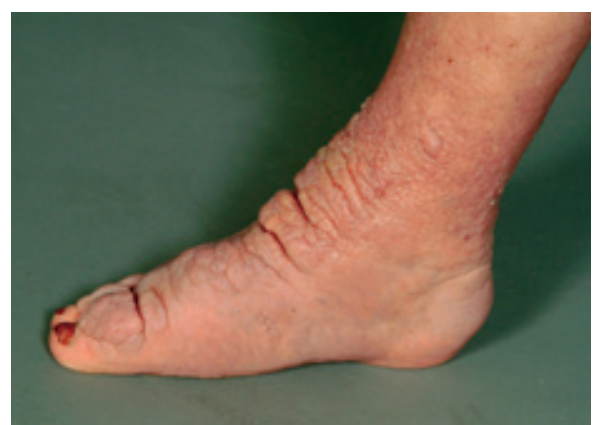

Figur 2 Nærbilde av figur 1. Blekrosa hud med papillomatøs overflate over tær og fotrygg som danner tumorliknende lesjoner 
Målcellen for denne autoimmune prosessen er fibroblaster i orbita, dermis og i synovialhinnen (1). I orbita medfører fibroblastaktiveringen både økt syntese av hyaluronsyre og økt antall adipocytter ved at fibroblastene transformeres til adipocytter. De kliniske symptomene ved exophthalmus forklares ved at øyeeplet presses utover på grunn av plassmangel ved økt retrobulbært volum. Dette kan gi venøs stase med risiko for kompresjon av strukturer i orbita. Ødem i muskulatur kan gi akkomodasjonsforstyrrelser. Aktivering av synoviale fibroblaster gir ødem i bløtvev og subperiostal beindanning med osteoartropati som følge.

Hvis thyreoideadermopati koeksisterer med exophthalmus og fortykkelse av fingrenes ytterledd, oppfylles kriteriene for EMOsyndrom (exophthalmus, myksødem og osteoartropati) (1). EMO-syndrom er svært sjeldent og kan utvikle seg langsomt på tross av godt regulert thyreoideafunksjon (1). Syndromtriaden innledes oftest av oftalmopati som vanligvis ses i løpet av 12 måneder etter debut av Graves' sykdom (1). Pretibialt myksødem utvikles vanligvis $12-24$ måneder senere, men i en studie fikk $12 \%$ av pasientene diagnostisert lokalisert myksødem hele 4-12 år etter utviklet sykdom (1). Osteoartropatien manifesterer seg hyppigst ved fortykkelse av av fingrenes ytterdeler og ses hos $25 \%$ av pasientene med utviklet pretibialt myksødem. EMO-syndrom har således et forutsigbart forløp, men det er likevel ikke mulig å forutsi hvilke av pasientene med Graves' sykdom som utvikler dette. Tilstanden indikerer en alvorlig autoimmun lidelse.

Det ble startet behandling med kompresjon på 20-30 mm Hg, og hun ble henvist til lymfedrenasjeterapi. Ved kontroll fire måneder senere var tilstanden uforandret. Hun hadde brukt gruppe II-steroid lokalt daglig i to måneder, men etter det sluttet hun fordi hun ikke syntes det hjalp.

Lettere tilfeller av myksødem trenger ikke behandling hvis tilstanden ikke er kosmetisk skjemmende for pasienten. Det er sett effekt etter 4-6 uker med lokale steroider (gruppe II-IV), ev. under okklusjon med kolloidplater (Duoderm) $(1,3)$ og vedlikeholdsbehandling 1-2 ganger per uke videre. Intralesjonelle steroider har også vist effekt (4). Mer alvorlige tilfeller er vanskelige å behandle og det anbefales kompresjon med trykkmansjett på 20-40 mm Hg og lymfedrenasjebehandling hos fysioterapeut (3). Det er beskrevet varierende effekt av subkutan eller intralesjonell octreotid (somatostatinreseptoragonist, Sandostatin) (5). Det er rapportert kasuistikker med god effekt av systemisk pentoksyfyllin som inhiberer proliferasjon og aktivering av fibroblaster (4, 6). Ultralyd av lesjonene kan brukes til monitorering av behandlingsrespons (4). Kirurgisk intervensjon er forbundet med stor risiko for residiver $(3,4)$.

\section{Andre kliniske erfaringer}

En kvinne utviklet Graves' sykdom da hun var rundt 20 år gammel. Hun ble da behandlet med radioaktivt jod og senere substitusjonbehandlet med tyroksin. Hun utviklet en tumor lateralt på venstre legg vel 15 år senere. Cytologisk undersøkelse viste mulig pleomorft lipom ev. høyt differensiert liposarkom. Lesjonen ble eksidert og dekket med delhud fra lår. Histologiske prøver viste uventet funn av myksoid vev forenlig med pretibialt myksødem. Noen måneder senere utviklet hun residiv på samme sted samt forandringer $\mathrm{i}$ transplantatområdet på låret (fig 3). Biopsi fra begge steder viste myksødem. Hun hadde også exophthalmus og de ytterste delene av fingrene var fortykket. Forandringene ble behandlet med en gruppe IV-salve under okklusjon med god effekt.

\section{Diskusjon}

Thyreoideadermopati forekommer særlig i tidligere traumatiserte hudområder $(1,3)$. Dette illustreres hos pasienten som utviklet myksødem både i hudtransplantatet pretibialt og i transplantatområdet på låret. Tilsvarende funn er tidligere rapportert hos en 47 år gammel kvinne som utviklet myksødem i et hudtransplantat på leggen ett år etter gjennomgått radiojodterapi grunnet Graves' sykdom. Transplantasjon ble utført pga. en hudskade etter en motorsykkelulykke 19 år tidligere med donorsted fra lår (7). Det er således holdepunkter for at traumatisering av hud kan gi en «købnerreaksjon» der aktiverte fibroblaster øker produksjonen av glykosaminoglykaner. Hydrostatisk trykk i legg er oppfattet som tilstrekkelig mekanisk traume for pretibialt myksødem $(1,3)$. Rapoport og medarbeidere fant tilstedeværelse av TSH-reseptorer både $\mathrm{i}$ frisk hud og i hud med myksødem (8). De konkluderer med at reaksjon mellom TSH-reseptor og fibroblaster ikke alene er nok for utvikling av myksødem. Traumatisering av hudområdet er i tillegg nødvendig. Fibroblaster har tradisjonelt vært sett på som immunologisk passive celler og produsenter av ekstracellulær matriks. Det er økende holdepunkter for at fibroblaster er aktive immunceller med frigjøring av immunmodulerende faktorer, som cytokiner og vekstfaktorer (9). Myksødem kan således være subklinisk i store hudområder inntil endringer i lokale forhold stimulerer fibroblastene (3).

Begge pasientene våre hadde utviklet EMO-syndrom etter radiojodbehandlet Graves' sykdom. Det er sett at ekstratyreoidale manifestasjoner ved denne sykdommen forekommer hyppigere etter radiojodterapi, spesielt hvis den er utført uten steroidparaply (10). En mulig forklaring er funn av økt mengde TSH-reseptorantistoff $i$ sirkulasjonen kort tid etter radiojodterapi og dermed økt immunologisk aktivitet (10). Røyking er rapportert å gi økt risiko for utvikling av $\operatorname{EMO}(1,3)$. Pasientene nevnt $\mathrm{i}$ vår artikkel utviklet myksødem over ti år etter diagnostisering av Graves' sykdom. Den lange latenstiden viser lang-

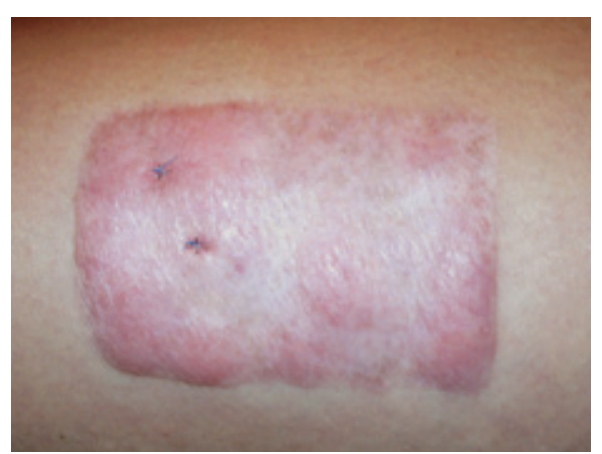

Figur 3 Thyreoideadermopati i transplantatområdet på venstre lår hos en kvinne i slutten av 30-årene

varig autoimmun aktivitet. Røyking kan være en faktor som forsterker den immunologiske aktiviteten analogt til det vi ser ved andre autoimmune lidelser som revmatoid artritt (1).

\section{Konklusjon}

Mucinavleiring i hud ved Graves' sykdom kan over tid gi utvikling av lymfødem. Det bør tas hudbiopsi hos pasienter med lymfødem av uklar genese. Pasienter med Graves' sykdom bør informeres om muligheten for utvikling av pretibialt myksødem. De bør starte tidlig med kompresjonsbehandling. Kirurgisk behandling kan forverre tilstanden

\section{Tone Kristin Bergersen}

kristin.bergersen@rikshospitalet.no

Hudavdelingen

Rikshospitalet

0027 Oslo

\section{Cato Mørk}

Hudavdelingen

Rikshospitalet

og

Det medisinske fakultet

Universitetet i Oslo

Pasienten har gitt samtykke til at artikkelen blir publisert.

Oppgitte interessekonflikter: Ingen

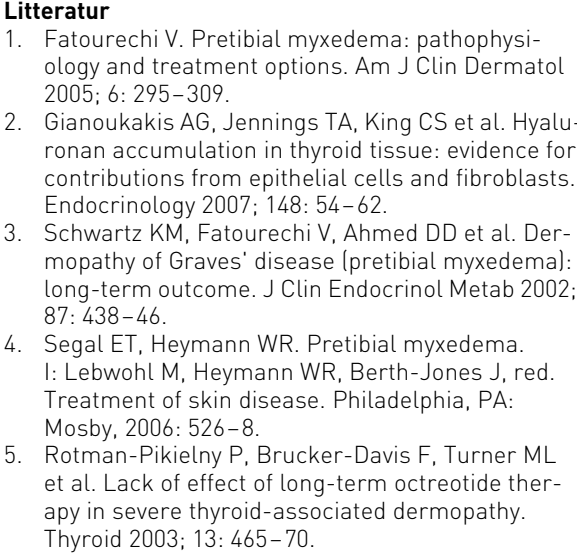

2. Gianoukakis AG, Jennings TA, King CS et al. Hyaluronan accumulation in thyroid tissue: evidence for contributions from epithelial cells and fibroblasts. Endocrinology 2007; 148: 54-62.

3. Schwartz KM, Fatourechi V, Ahmed DD et al. Der mopathy of Graves' disease (pretibial myxedema): long-term outcome. J Clin Endocrinol Metab 2002; 87. $438-46$.

4. Segal ET, Heymann WR. Pretibial myxedema I: Lebwohl M, Heymann WR, Berth-Jones J, red. Treatment of skin disease. Philadelphia, PA: Mosby, 2006: 526-8.

5. Rotman-Pikielny P, Brucker-Davis F, Turner ML et al. Lack of effect of long-term octreotide therapy in severe thyroid-associated dermopathy. Thyroid 2003; 13: 465-70. 
6. Pineda AM, Tianco EA, Tan JB et al. Oral pentoxifylline and topical clobetasol propionate ointment in the treatment of pretibial myxoedema, with concomitant improvement of Graves' ophthalmopathy. J Eur Acad Dermatol Venereol 2007: 21: 1441 -3.

7. Schwartz KM, Ahmed DD, Ahmed I et al. Development of localized myxedema in a skin graft. Int J Dermatol 2002; 41: 401-3.

8. Rapoport B, Alsabeh R, Aftergood D et al. Elephantiasic pretibial myxedema: insight into and a hypothesis regarding the pathogenesis of the extrathyroidal manifestations of Graves' disease. Thyroid 2000; 10: 685-92.

9. Smith TJ. Insights into the role of fibroblasts in human autoimmune diseases. Clin Exp Immunol 2005; 141: 388-97.

10. Bartalena L, Marcocci C, Bogazzi F et al. Use of corticosteroids to prevent progression of Graves ophthalmopathy after radioiodine therapy for hyperthyroidism. N Engl J Med 1989; 321: 1349-52.
Manuskriptet ble mottatt 21.4. 2008 og godkjent 20.11. 2008. Medisinsk redaktør Odd Terje

Brustugun.

\section{Kommentar}

\section{Hudforandringer som diagnostisk hjelpemiddel}

Hudmanifestasjoner ved autoimmune endokrine sykdommer kan sammen med god anamnese og kiniske undersøkelser raskt føre til korrekt diagnose, noe Tone Kristin Bergersen \& Cato Mørk illustrerer med sine kasuistikker. Ved Graves' sykdom som deres artikkel omhandler, dannes autoantistoffer mot thyreoideastimulerende hormon (TSH)- reseptoren. Oftest er autoantistoffene stimulerende og resultatet blir økt hormonproduksjon. De samme antistoffene er trolig også involvert i utviklingen av sykdom utenfor thyreoideakjertelen; høye nivåer av TSH-reseptorantistoffer trigger og vedlikeholder både oftalmopati og dermopati (pretibialt myksødem). Graves' sykdom inngår $i$ en gruppe autoimmune sykdommer der autoantistoffer enten stimulerer eller blokkerer reseptorer. Best kjent er autoantistoffer mot acetylkolinreseptoren ved myasthenia gravis og autoantistoffer mot spenningsregulerte kalsiumkanaler ved LambertEatons myastenisk syndrom, sistnevnte et paraneoplastisk fenomen ved småcellet lungekreft. Mindre kjent er stimulerende antistoffer mot kalsiumsensorreseptor på parathyreoideacellene som gir hypokalsemi (1) og nylig rapporterte inhiberende antistoffer mot melanocortin-4-reseptoren med overvekt til følge (2).

Også ved hypotyreose er forandringer i huden fremtredende. Ved uttalt hypotyreose øker glykosaminoglykanmengden i huden slik at et generelt myksødem utvikles. Dette er ofte best synlig periorbitalt i tidlig sta- dium (3); huden blir samtidig gulig misfarget av karotenopphopning. Leggene er ofte et predileksjonssted for autoimmune hudmanifestasjoner, slik det er for Graves' dermopati. Hos diabetikere finner man ofte nekrobiosis lipoidica lokalisert her. Dette er distinkte velavgrensede plakk med rødbrun farge og av varierende størrelse som vokser utover og ofte ulcererer. Årsaken er ukjent, men i likhet med Graves' dermopati, kan traume være utløsende. Erythema nodosum, en postinfeksiøs immunologisk reaksjon etter blant annet streptokokkinfeksjoner og tuberkulose, er typisk også lokalisert på leggenes forside.

Flekkvist hårtap (alopecia areata) og pigmenttap i hud (vitiligo) er hyppig assosiert med autoimmunitet (3), blant annet ved Graves' sykdom og type 1-diabetes, men også ved mange andre autoimmune sykdommer. Funn av vitiligo og alopesi bør føre legens tanke til autoimmun sykdom og disposisjon.

Det er likevel ikke alltid at hudmanifestasjonen i seg selv er immunologisk betinget. Ved primær binyrebarksvikt er et av de få typiske tegnene en uttalt hyperpigmentering av hudområder utsatt for soleksponering og friksjon, noe som gir den klassiske pigmenteringen av knoker og bøyefurene i hendene (4). Relatert til hyperpigmentering er også acanthosis nigricans som er hyperpigmenterte, fortykkede, papillære hudforandringer typisk lokalisert $\mathrm{i}$ armhule, lyske og nakke (3). Tilstanden ses ved overvekt med insulinresistens, eventelt type 2-diabetes.
Acanthosis nigricans kan også være et paraneoplastisk fenomen, hyppigst rapportert ved adenokarsinomer i gastrointestinaltractus og ved underlivskreft.

Vurdering av huden hører til en god klinisk undersøkelse. Mange autoimmune sykdommer, ikke bare de endokrine, gir hudforandringer som kan være nyttige diagnostiske hjelpemidler.

\section{Eystein Sverre Husebye}

eystein.husebye@helse-bergen.no

Institutt for indremedisin

Universitetet i Bergen

og

Medisinsk avdeling

Haukeland universitetssykehus

5021 Bergen

Oppgitte interessekonflikter: Ingen

\section{Litteratur}

1. Kifor O, McElduff A, LeBoff MS et al. Activating antibodies to the calcium-sensing receptor in two patients with autoimmune hypoparathyroidism. $J$ Clin Endocrinol Metab 2004; 89: 548-56.

2. Peter JC, Bekel A, Lecourt AC et al. Anti-melanocortin-4 receptor autoantibodies in obesity. J Clin Endocrinol Metab 2009: 94: 793-800.

3. Jabbour SA. Cutaneous manifestations of endocrine disorders: a guide for dermatologists. Am J Clin Dermatol 2003; 4: 315-31.

4. Løvås K, Husebye ES. Addison's disease. Lancet 2005: 365: 2058-61.

Manuskriptet ble mottatt 15.1. 2008 og godkjent 26.1. 2008. Medisinsk redaktør Odd Terje Brustugun. 